\title{
Arctic climate change discourse: the contrasting politics of research agendas in the West and Russia
}

\author{
Bruce C. Forbes ${ }^{1}$ \& Florian Stammler ${ }^{1,2}$ \\ 1 Arctic Centre, University of Lapland, Box 122, Fl-96101 Rovaniemi, Finland \\ 2 Scott Polar Research Institute, University of Cambridge, Lensfield Road, Cambridge, CB2 1ER, UK
}

\section{Keywords}

Arctic Russia; Nenets nomads; oil and gas development; reindeer herding; TEK; wildlife co-management.

\section{Correspondence}

Bruce C. Forbes, Arctic Centre, University of Lapland, Box 122, Fl-96101 Rovaniemi, Finland. E-mail: bforbes@ulapland.fi

doi:10.1111/j.1751-8369.2009.00100.x

\begin{abstract}
In this paper we explore how Western scientific concepts and attitudes towards indigenous knowledge, as they pertain to resource management and climate change, differ from the prevailing view in modern Russia. Western indigenous leaders representing the Inuit and Saami peoples are actively engaged in the academic and political discourse surrounding climate change, whereas their Russian colleagues tend to focus more on legislation and self-determination, as a post-Soviet legacy. We contribute to the debate with data from the Nenets tundra, showing how different research has employed the three crucial Western research paradigms of climate change, wildlife management and indigenous knowledge on the ground. We suggest that the daily practice of tundra nomadism involves permanent processes of negotiating one's position in a changing environment, which is why "adaptation" is woven into the society, and cosmology as a whole, rather than being separable into distinct "bodies" of knowledge or Western-designed categories. We argue that research agendas should be placed in their proper local and regional context, and temporal framework: for example, by collaborating with herders on the topics of weather instead of climate change, herding skills instead of wildlife management, and ways of engaging with the tundra instead of traditional ecological knowledge.
\end{abstract}

Certain parts of the Arctic have experienced more significant and rapid climate change than others in recent decades (Symon et al. 2005; Solomon et al. 2007). In the Yamal-Nenets Autonomous Okrug (YNAO), on the northern edge of Russia's West Siberian plain (Fig. 1), the average summer air temperatures have increased some $2{ }^{\circ} \mathrm{C}$ over the past 25-30 years (GISS 2009), with the greatest warming taking place in the spring and summer. Only portions of northern Alaska and the western Canadian Arctic have warmed to a comparably high level during the same time period. The predicted and observed ecosystem responses around the Arctic include: increasing shrub abundance (Chapin et al. 1995; Shvartsman et al. 1999; Sturm et al. 2001); changes in precipitation and snow cover regimes (Sturm et al. 2005; Serreze \& Francis 2006); warming and thawing permafrost; drying lakes and wetlands, and increased fluxes of greenhouse gases, such as carbon dioxide and methane (Hinzman et al. 2005; Zimov et al. 2006). Satellite images have already detected an overall "greening" of the Arctic since the early 1980s, indicating what is believed to be a significant increase in biological productivity at the biome level (Jia et al. 2003).

During this most recent period of Arctic warming, much of the literature concerning indigenous knowledge and observations of Arctic environmental change has derived from North America (Berkes \& Jolly 2001; Riedlinger \& Berkes 2001; Krupnik \& Jolly 2002). Scientists and local communities have together documented striking changes in weather, snow and ice patterns, which strongly affect hunting conditions. At the same time, changes in the timing, movements and behaviour of key game species have caused concern among Northerners, as they struggle to understand and cope with new and unfamiliar sets of parameters governing access to and quality of both animal and plant resources (Fox 2002; Jolly et al. 2002; Kofinas et al. 2002). Meanwhile, since the mid1980s, Arctic Russia has been characterized by upheaval in the form of perestroika, glasnost, the collapse of the Soviet Union and a post-Soviet period of marked political 


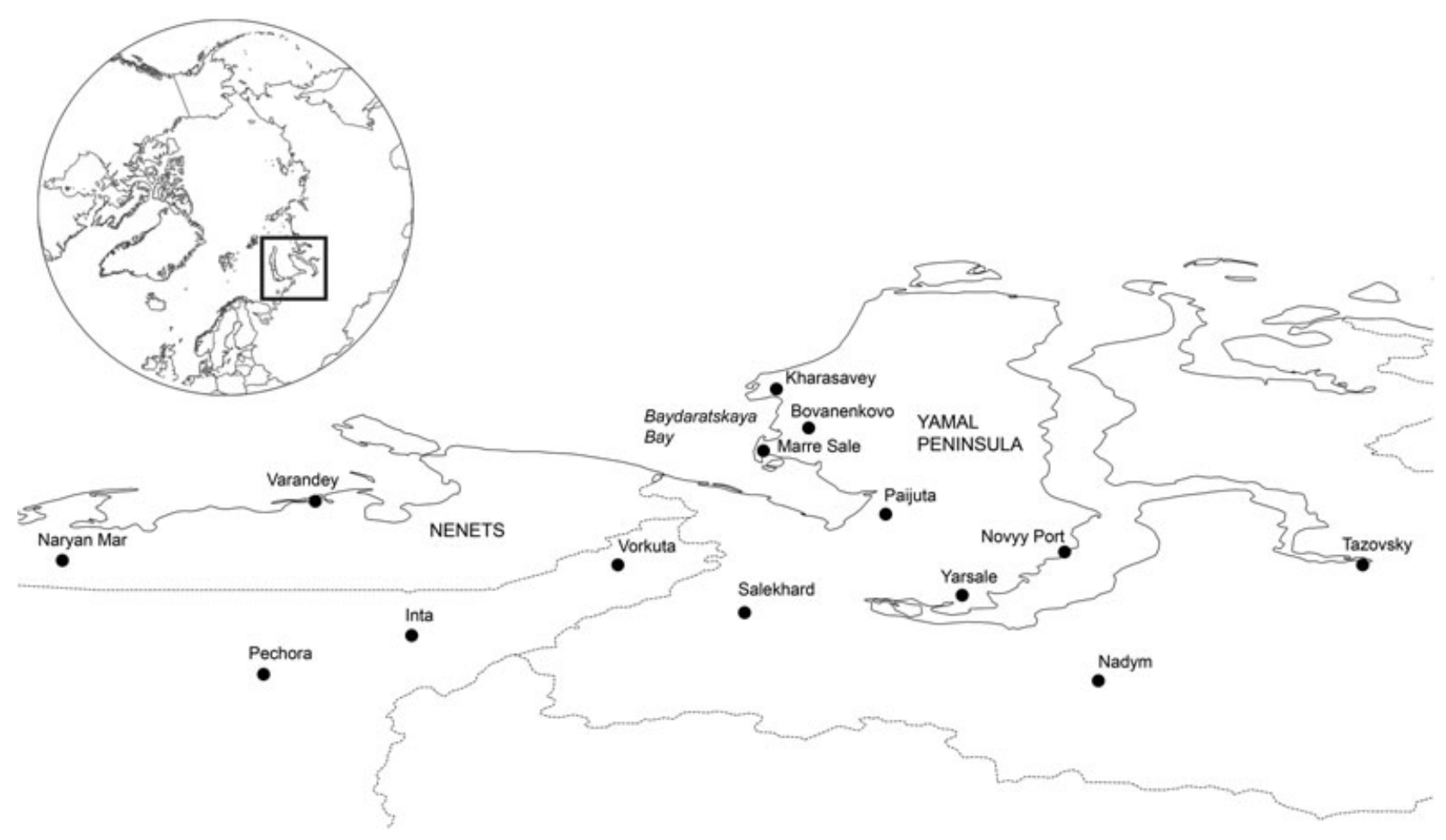

Fig. 1 Map showing the location of the Nenets and Yamalo-Nenets autonomous okrugs in northern Russia.

and socio-economic instability (Krupnik 2000; Stammler 2005). This has only begun to stabilize in recent years under President Putin. It is for these socio-political reasons that climate change has not been at the top of the agenda so far in the Russian North, as local inhabitants perceive that there are more pressing problems to address.

The nomadic Nenets reindeer herders of the Yamal Peninsula spend most of their lives on the land, and in close contact with their animals (Stammler 2005). They also spend significant periods of time fishing, hunting and gathering. The longest annual migrations take place between the northernmost reaches of the Boreal forest and the northern tundra along the Kara Sea coast. This time on the land year after year necessitates the development and maintenance of highly complex social and ecological skills, and other forms of knowledge. By spending time on the land, the relationship between humans and animals is enacted, and, in this context, skills develop and knowledge evolves through practice (Ingold 2000). Most of the Nenets reindeer herders still lead a fully nomadic way of life: only certain groups of the European Nenets Autonomous Okrug (NAO) have been relocated into settlements, and are now partly nomadic, which makes them interesting for comparisons of herding techniques and skills with the full-time nomads. The Nenets' nomadic existence contrasts with the situation in
Arctic North America and northernmost Europe, where virtually all indigenous peoples were relocated into fixed settlements by the late 1950s and early 1960s, for purposes of sovereignty, education, religious indoctrination and law enforcement (Armstrong et al. 1978; Wenzel 1991; Einarsson et al. 2004). In what is now Nunavut, many of these settlements grew out of fur-trading posts that had originally been set up as by the Hudson's Bay Company (Wenzel 1991).

In this paper we explore the idea that Western scientific concepts and approaches to documenting indigenous knowledge, as it pertains to climate change, differ dramatically from what we find to be a viable approach in Arctic Russia. In the West, indigenous groups such as Inuit and Saami are actively engaged in the academic and political discourse surrounding climate change (Turi 2000; Fox 2002; Jolly et al. 2002; Tyler et al. 2007), in some cases acting as the initiator of research projects during the ongoing International Polar Year (IPY). In the North American Arctic, which has a long history of dialogue concerning wildlife harvest via various co-management regimes, people are accustomed to debating long-term trends in environmental conditions and animal population dynamics (Treseder 1999; Caulfield 2004; Nadasdy 2003, 2005; Stevenson 2006; White 2006).

Based on the long-term research of both authors in the YNAO and NAO, we introduce the dominant discourse on 
changes in the Russian sector of the Arctic, where rapid changes in the environment and in the socio-economic framework are also intensively perceived, evaluated and addressed by local people, but along different lines, which are not possible to capture with Western concepts and terms such as climate change, wildlife management or traditional ecolological knowledge (TEK). The authoritative Intergovernmental Panel on Climate Change (IPCC) defines climate change as any long-term significant change in the "average weather" that a given region experiences (Solomon et al. 2007: 96). Average weather may include average temperature, precipitation and wind patterns (Solomon et al. 2007). According to a recent textbook, wildlife management is the process of keeping certain wildlife populations, including endangered animals, at desirable levels determined by wildlife managers (Bolen 8 Robinson 2002). Probably the most widely cited definition of TEK is that of Berkes (1999), wherein TEK is defined as a body of knowledge, practice and beliefs about the dynamic relationship of living beings with one another, and with their environment, which has evolved by adaptive processes, and has been handed down from generation to generation. A less cited but useful distinction is made by Ingold \& Kurttila (2000: 184) between "traditional knowledge as enframed in the discourse of modernity" and "traditional knowledge as generated in the practices of locality". Our own research shows that coexistence among different user groups on the land, as well as environmental change, is intensively discussed on the ground in Russia. However, research investigating only institutionalized discourses and official participation regimes will not be able to capture this, because both the discourse and the institutions differ strongly. In this paper we will critique the theory and practice of community-oriented research in modern Arctic Russia.

\section{Climate change, wildlife management and TEK: the politics of research agendas in the West and Russia}

We argue that the current scientific agenda surrounding change in the Arctic is largely dominated by three terms that are shaped by the Western research community. This community maintains an apparatus that shapes, through the channeling of grants and the organization of large synthetic processes (e.g., the Arctic Climate Impact Assessment [ACIA] and the IPCC), a dominant discourse that claims relevance for the whole of the Arctic. On the other hand, the terms climate change, wildlife management and TEK are rather recent introductions to the Russian North, as they were designed by Western scientists and politicians.
Unlike the situation in the West, in Russia, climate change has not taken over the scientific agenda from other topics that people find more pressing. In Russia, many scientists and politicians react skeptically and defensively to what they perceive as another form of Western-dominated political agenda designed to absorb Russian expertise. Even though much research has already been undertaken, particularly in the natural sciences, on changes in temperature, vegetation and permafrost, and although local people have extensive knowledge of these changes, the results of such research are not yet taken as evidence of a directional change of climate caused by humans. Ironically, skepticism, and at times even polemical comments against what might be called "climate change obsession", are often expressed behind closed doors by researchers hired with Western money to provide data for climate change projects in which they themselves do not believe. Such discourse is hardly published in academic journals, but is often a dominant topic during informal conversations in Russian among scientists at conferences. Stammler has often witnessed this: for example, at Arctic Operational Platform project meetings (2005), during visits of Siberian government delegations to the Scott Polar Research Institute in Cambridge (2005) and the Arctic Centre (2006) in Rovaniemi, at the Institute for Permafrost Studies in Yakutsk, Siberia (2001), and during the Arctic Marine Transport workshop at the Scott Polar Research Institute (2004).

Along similar lines, previous studies have convincingly argued that the very concept of "wildlife" is a Westerncentric construct that serves to create "exotic difference" with the dominant urban way of life (Beach 2000; Dahlstrom 2003). In fact, "wildlife" as a category is a concept based on the idea of a separation of humans and nature, and has been introduced for the anthropocentric management of ostensibly "untouched" areas referred to as "wilderness". For local and indigenous people who use these areas, these concepts are not very meaningful (Forbes 2005). The idea of the Judeo-Christian-inspired human-environmental relations is to seek dominion over nature (Nash 1982). Along the same lines, Soviet intellectuals conceptualized nature with the goal of harnessing it for the needs of communist society (Weiner 1988; Bolotova 2004). This approach is in stark contrast to indigenous cosmologies, where there is no humannature divide (Stammler 2005), and where humans are a part of a "sentient ecology" (Anderson 2000; Natcher et al. 2007).

The third "Western import", TEK, was "created" as a category in order to accommodate the knowledge that indigenous people had accumulated during centuries into scientific discourse. Although TEK has almost universally 
been validated as a concept for indigenous communityoriented research in the West, in doing so it has become firmly "enframed in the discourse of modernity" (Ingold \& Kurttila 2000). However, research in Russia has shown that this category does not mean much to the people on the ground. This has led to misunderstandings, as if the people had "lost" their TEK as a result of Soviet assimilation, and supposedly did not understand nature any more (Muraško, pers. comm. 2007; Stammler, pers. obs.). In fact, it is just that they do not conceptualize their expertise on the land along the same lines, a critique that has also been made by some Western observers of TEK and attempts at implementing it within Arctic co-management regimes (Nadasdy 2003, 2005; Stevenson 2006; White 2006). Reindeer herders have a much more processual perception of their role on the land, in the sense of Ingold's "human-agent-in-the-environment" approach (Ingold 2000), or Anderson's "sentient ecology" (Anderson 2000; see also Natcher et al. 2007). According to these ideas, we cannot speak about a "body of knowledge", but should rather focus on the ways of knowing (Vitebsky 1995; see also Kendrick 2003; Huntington 2005) that people enact in their diverse activities on the land. As a process, these ways of knowing accommodate environmental changes continually, as they are encountered (Stammler 2005; Vitebsky 2005; Kitti et al. 2006). This is analogous to what Ingold \& Kurttila (2000: 184) refer to as "traditional knowledge as generated in the practices of the locality", indicating that even they do not reject the notion of knowledge as a noun altogether.

In North America, for better or worse, co-management has institutionalized the discussion of the population dynamics of species that are acknowledged to fluctuate over decadal time scales, in response to climatic and other factors (Vibe 1967; Nadasdy 2003, 2005; Symon et al. 2005; Stevenson 2006). At the same time, the weather conditions that allow the harvesting of certain animals can vary greatly from year to year (Nelson 1969; Wenzel 1991; Krupnik 1993). As such, Northern peoples seek a direct and sometimes powerful stake in policy-relevant research, and in management decisions concerning hunting, fishing and gathering in the context of ongoing climate change (Kofinas et al. 2002).

By comparison, Russia's indigenous peoples, including the Nenets, do not have the same level of political clout as those in Western countries. For example, Sheila-Watt Cloutier, former President, Vice-President and International Chair of the Inuit Circumpolar Conference (ICC), was nominated for the Nobel Peace Prize in 2007, in recognition of her effective activism in raising awareness of climate change in the Arctic and globally. Nenets do not have such a prominent political voice, either inside or outside of Russia's borders. This difference distinctly colours the discourse concerning climate change. We caution against a rush to analyse adaptation to ongoing rapid climate change through the eyes of the Nenets by using prevailing Western approaches. Later in our analysis we will advocate an alternative approach that places greater emphasis on local concerns for developing mutually acceptable research agendas. Nenets practice adaptation in a number of spheres, including, but not limited to, weather, climate and large-scale petroleum development. Climate change and adaptation must therefore be placed in their proper context and temporal framework.

Part of this context is that the last two decades have seen considerable indigenous empowerment in the West compared with that in Russia. Within this framework, climate change has only recently taken over as the main topic of concern in indigenous politics, exemplified by the lawsuit of the ICC against the Bush administration in December 2003 (Brown 2003). Among the main messages from this empowerment was that indigenous people do not feel victimized, exposed to pressures with which they have to cope. Rather, some Inuit prefer to take a proactive role, displaying agency in meeting the challenges (Griffiths 2007). This attitude has also found its way into interdisciplinary research projects, where indigenous researchers work alongside natural scientists and anthropologists on climate change topics (Krupnik \& Jolly 2002; Kruse et al. 2004). In Russia, the situation is also changing now. Recent research has conceptualized the indigenous people as one component of the interaction between humans and environment in the whole system. This approach incorporates indigenous peoples' agency, i.e., their role in influencing the changes themselves on the ground (Habeck 2005), instead of seeing them merely as the victims of outside pressures. Indigenous agency is mainly perceived with regard to the increasing industrialization of the Russian North, and it is within this sphere where Russian indigenous representatives are most pro-active (Okotetto \& Forbes 1999; Khorolya 2002; Stammler \& Peskov 2008). This focus reflects the much more urgent concern among Nenets with regard to industrialization. Although climate change may also represent a threat to the long-term viability of Nenets reindeer nomadism, for now, local Nenets are particularly preoccupied with the coexistence of reindeer herding and oil and gas activities. A critical difference between research processes concerning climate change, or industrialization, may be that in the latter case independent studies focusing on perception and agency on the ground can meet with opposition by indigenous leaders and municipalities anticipating revenues, whereas in the former case research has been very much supported by indigenous leaders. 
Research based on the three crucial concepts of wildlife management, climate change and TEK are now in the process of being introduced to or even imposed on the Russian North, for example, through the journal of the Russian Association of Indigenous Peoples of the North, as well as through Western-led IPY research projects. If indigenous peoples want their voices to be heard, they need to buy into the process or they will lose out. In this paper we track this process, and highlight aspects of the local understanding of human relations with their environment. The terms and conditions are being set now by politics, as a result of Russia being more integrated into Western scientific discourses. Thus, the changing atmospheric weather influences the dialogue of Nenets herders with their environment, whereas the changing "political weather" influences the way in which this dialogue is presented to the outside world.

Having argued this, we caution at the same time against a simplistic dichotomy between "the West" and "the rest". Therefore, it would be misleading to claim that Russian indigenous people are only passively subordinate to their dominant society, whereas their Western counterparts are actively pursuing their agenda (see Habeck 2005). Russian indigenous politicians are active participants in Russian political life, and have gained a much greater influence than the proportion of their people within the general Russian population would suggest. This is particularly true for the northern provinces that are strongly engaged in hydrocarbon extraction, where indigenous leaders were instrumental in passing three federal laws regulating their political and economic rights, as well as amending many of the basic Russian laws (Stammler \& Wilson 2006).

Rather than reifying dichotomies, we suggest that analysing the dynamics occurring in the Russian case can facilitate understanding general processes that have already happened in other regions of the globe, revealing the principles according to which contemporary human societies are organizing their relations with their environment, and the ongoing struggle to navigate between different livelihoods. The divide is therefore more along the lines of organizing scientific data in abstract categories on the one hand, and practices on the land on the other hand, being the result of lived experience and dynamically negotiated human-animal-environment relations. This mirrors Ingold's $(2005,2007)$ argument against the divide between nature and humans, and parallels the traditional separation between natural and social sciences. The problem, as he convincingly showed, is that contemporary scientific discourse fails to integrate what actually belongs together in the analysis, because not only indigenous people, but any human agent in the environment, enact practices embracing social, natural and spiritual aspects of lived experiences.

\section{Co-management, TEK and the history of power sharing in North America}

The development of state relations with regard to Arctic resource governance can differ significantly between countries, but in general, the contrast is greatest between Western countries and Russia. In a North American context, co-management commonly refers to a shared decision-making process, formal or informal, between a government authority and a user group for managing a species of fish, wildlife or an other resource (Caulfield 2004). The functions of co-management with respect to wildlife include data gathering and analysis, and harvest allocation and regulation. As such, co-management comprises a continuum of different power-sharing arrangements (Berkes et al. 2007), which in general is believed to enhance the collection and exchange of information on wildlife resources (Treseder 1999; Nadasdy 2003).

To meet the challenges of community sustainability, Arctic indigenous peoples in North America have stated their insistence on being involved in all functions of resource management, and in that process they expect their cultural perspectives to be respected (Kofinas et al. 2002). According to Berkes \& Jolly (2001)

newly developing co-management institutions create additional linkages for feedback across different levels, enhancing the capacity for learning and self-organization of the local inhabitants and making it possible for them to transmit community concerns to regional, national, and international levels.

At the same time, one of the most difficult and controversial issues in North American wildlife co-management is the indigenous peoples' use of TEK (Treseder 1999; Huntington 2000; Usher 2000; Nadasdy 2003, 2005; Stevenson 2006). Berkes (1999) divides TEK into three components, which comprise a "knowledge-practicebelief" complex. The first sphere is knowledge of the surrounding animals and plants, and also of the behaviour of animals. The second is to practice the knowledge in their livelihood as hunters, fishermen or herders, and the third sphere is the belief system in which events are interpreted in a certain way. This division into "complexes" or "bodies" is a typical example of "traditional knowledge as enframed in the discourse of modernity", whereas in "traditional knowledge as generated in the practices of locality" (Ingold \& Kurttila 2000: 184), these spheres are inseparably interlinked in the context of human agents in an animate environment. 
Context is an essential issue in the use of TEK, given that the imposed construct for North American "wildlife management" (including co-management) is Western science (Treseder 1999; Nadasdy 2005). A key discussion in North America therefore centres on determining approaches that offer the benefits of knowledge co-production to address the substantive concerns surrounding climate change, while at the same time remaining sensitive to local cultures (Kofinas et al. 2002). However, even co-production as an approach is more closely related to knowledge as a noun, and the management thereof. We therefore suggest that meaningful academic-practitioner cooperation requires the joint involvement of scientists and local residents practicing on the land, so that on both sides joint fieldwork results in a "co-evolvement of knowing", which is a practiceoriented and dynamic process.

The Canadian case is a good illustration of how the rights of Northern residents to wildlife are intimately related to the wider topic of aboriginal rights, which have developed over more than two centuries. Such rights date back to at least the Royal proclamation of 1763, which has been referred to as "an early comprehensive claims policy" (Treseder 1999). Although protection has varied among regions since that time, constitutional documents have continued to recognize the concept of aboriginal rights. Nadasdy argues

that the development of the institutions and practices of state wildlife management at the beginning of the 20th century was inextricably bound up with the expansion of state power. In many parts of the world, including North America, it was the imposition of state wildlife management and conservation programs that first brought not only land and wildlife but also local and indigenous people under the effective control of central governments.

(Nadasdy 2007: 212-213)

The modern era began with the 1969 White Paper by the Trudeau government, which served as a catalyst for the development and growth of increasingly influential indigenous organizations. The resolution of indigenous interests was a necessary precursor to northern development. Specific interest in the oil and gas resources of the Arctic, particularly in the Beaufort Sea, was a key motivator for documenting the extent of indigenous resource use (e.g., Usher 1971; Berger 1977), and spurred the settlement of some comprehensive claims (Doubleday 1989; Treseder 1999). The discovery of oil across the border at Prudhoe Bay in 1968 similarly led to a sweeping land claims settlement in Alaska (Young 1992).

The James Bay and Northern Quebec Agreement (JBNQA) of 1975 was the first modern comprehensive land claim in Canada. JBNQA gave the Cree and Inuit an equal share in wildlife management throughout the entire area covered by the agreement. Treseder (1999: 12) reports that "the JBNQA set the tone for future comprehensive claims in Canada, particularly in the northern territories, all of which include some form of comanagement of wildlife and other natural resources".

In both Canada (Treseder 1999) and Alaska (Huntington 1992), numerous single-species co-management initiatives have emerged when conventional government approaches have proven inadequate to deal with a real or perceived decline in wildlife numbers. Indigenous groups are strongly motivated by threats to reduce or stop hunting (Huntington 1992). One of the earliest examples of cooperative management is the Beverly-Qamanirjuaq Caribou Management Board, which was established in 1982 in response to a widely perceived crisis in the management of the herds of barren-ground caribou in the region (Treseder 1999).

Some have argued that co-management is necessary for the efficient and equitable management of wildlife (Osherenko 1988; Usher 1991). Indeed, the proponents of co-management take it for granted that its implementation will lead to improved wildlife management, and the empowerment of local First Nation communities (Nadasdy 2005). Indigenous rights within a comprehensive land claim settlement are protected not only by legislation implementing that claim settlement, but also by the Canadian Constitution (Treseder 1999). Co-management through comprehensive claims has become the dominant management regime for wildlife in Canada's northern territories (Northwest Territories, Yukon). As a result, some territories and provinces now have more than three decades of involvement in co-management, and this arrangement is expected to continue into the future (Treseder 1999).

\section{Modern Nenets' reindeer management in a warming climate}

The area inhabited by Nenets reindeer nomads hosts the world's largest concentration of domestic reindeer, around 800000 animals. Most of these animals are private property, owned by individual herders and therefore displaying their exclusive earmarks (Stammler 2005). Nenets reindeer herders manage their herds under close supervision. This means that the herd is within sight of a herder for 24 hours a day, most of the year. As a result, herders continually detect any changes on the ground, and assess these changes in their importance for their day-to-day herding and fishing decisions, as well as for their longer-term strategies. We cannot in this case speak of a "body of TEK" that continually accrues in the minds of the herders. Nonetheless, these herders are the 
most distinguished experts on their lands, even though some of them might never have heard of climate change, wildlife management or TEK. Their life of continuous movement is a process that is deeply embedded culturally, and the way in which they know and interpret changes is part of their nenei ilgnana ("real life", meaning a life of nomadic movement; Kharjuči 2001; Stammler 2005).

The property regime and the fully nomadic management entail a set of relations between humans, their animals and their surroundings, which is different from hunting societies in the American North. Correspondingly, in Russia there are no data on what are called "traditional economies" that are comparable with North American examples, e.g., animals are raised mostly as private property of herders, and not "harvested" (Stammler 2005: 26-27; Vitebsky 2005: 17-19), so there are no "harvest data". In some regions of Russia there was even a moratorium on reindeer slaughter altogether, and herders were paid to maintain live reindeer instead of produce dead reindeer (Stammler \& Ventsel 2003). This diversity of approaches has hampered the comparison of economic data from the North at the circumpolar level, in the "Arctic Social Indicator" efforts, for example (see also Einarsson et al. 2004). Discussions as part of these pan-Arctic efforts show the extent to which they are dominated by a scientific-political agenda that is primarily concerned with data and figures, rather than livelihoods and entitlements, with the latter being more important for practitioners not only in the Russian but also the "Western" Arctic.

Russian indigenous peoples have been involved with the state on a more permanent basis since the late 18th/ early 19th century. Earlier they were only subject to the fur tribute (yasak), but otherwise were not part of the political system. One of the first comprehensive legal acts governing their territories was the Speranskii code from 1822, which created three categories for the non-Russian populations of the Tsarist Empire, which were referred to as "alien" (inorodsy). Most of the nomads of the Arctic were classified as "wanderers" (brodiashchie), which meant they had the least rights, and also the least duties, of all subjects within the empire. At the same time, this law provided them with a very limited, basic form of self-government, the "clan administration" (rodovoe upravlenie; Pika 1999: 35-43; Stammler 2005: 123-124). However, because of their mobility and nomadism, the dominant sedentary population interpreted them as moving subjects without proper attachment to territories.

In the Soviet Union all land belonged to the state, which meant in theory to the people, and in practice to the Communist Party. As a legacy of this system, today the successor enterprises of the Soviet state farms (sovkhozy) are still the principle holders of land titles. There may be indigenous influence on the land in cases where the sovkhoz chairman is indigenous, and resists selling his sovkhoz to a gas company (Stammler 2005: 299). However, some of the enterprises are also run by managers from Moscow, Ukraine or other southern places.

Perestroika and the post-Soviet transformation in Russia brought the land rights discussion to the indigenous minority in the Russian North. In so far as the end of the Soviet Union brought private land ownership to Russia, land rights discussions are also influenced by the Western discourse of market capitalism, whereas land ownership has not previously been an indigenous concept, and even in the 21 st century, Nenets nomads did not think that the land should be divided among different owners (Stammler 2005: 237, 239). This discussion became most important in areas of industrial expansion, and consequently the Khanty-Mansiisk Autonomous Okrug (KMAO) in West Siberia, where most of the northern Russian oil has been extracted to date, passed the most advanced indigenous land title act. There, as of 1994, individual households as well as smaller communities had the right to apply for rodovye ugodia, "assigned clan territories", for which the law granted them individual, life-long, inheritable rights of use, free of charge. Industrial companies had to sign an agreement with the holders of these titles, where environmental and social terms and conditions were stipulated. This law was so influential in the region that within a few years about $1.5 \%$ of the population in the KMAO (indigenous people) controlled $33.8 \%$ of its territory on paper, which led to a perception of social injustice on the part of the non-indigenous majority in the region (Plotnikova 1997: 265). With the new land code of the Russian Federation (passed in 2001), this regional law actually became defunct. Instead, the Russian Federation passed (also in 2001 ) a law on "traditional nature use", which stipulates far-reaching rights of use (but not ownership) of the above-ground natural resources for eligible territories. However, implementation of that law has been seriously hampered by more powerful groups, favouring commercial development rather than indigenous economies (Muraško 2001).

Instead, many people, e.g., Nenets herders, have tried to secure land titles on a regional level, by establishing "peasant farming enterprises" or "indigenous communities" (obshiny korennykh narodov), both of which are covered by relevant legislation. However, none of these titles grant ownership, which in the contemporary Russian North remains fully with the state. Most recently, a new category of land rights for private reindeer nomads on the Yamal Peninsula, called "servitude", where 
migration routes of individual families are recognized and officially certified on maps, while the official land users are larger units, e.g., successors of state farms, with the state being the formal owner of the land, is planned. From all that we see, indigenous peoples are not given an active role, and there is no co-management history of natural resources. However, as the legislation increasingly requires the consultation of local residents, we do see the first attempts at co-management projects. One example includes the first pilot project called "ecological co-management of the extractive industry, the authorities and the indigenous peoples of the North", financed by the Russian ministry for natural resources for 2008. In that project, the emphasis lies on encouraging indigenous monitoring of environmental change resulting from industrialization, and mapping the nomadic land use of reindeer herders.

This, and another project run by the Nenets indigenous association with funding from abroad (Monitoring of Development in Traditional Indigenous Lands of the Nenets Autonomous Okrug), aims specifically to incorporate indigenous ways of knowing into applied research. Along similar lines, the Conservation of Arctic Flora and Fauna pilot project aimed to compile an inventory of sacred sites in the Yamal and Kamtchatka regions of the Russian North (Khariutschi et al. 2002). These projects include the study of Nenets decisions, and their rationale, in a research context that arose out of the necessity to develop indigenous agency when indigenous peoples meet with the rapidly expanding industry of the North.

Examples of this rationale are perceptions of vegetation change (see discussion of shrub growth below) and responses to it, rain-on-snow and refreezing events, and the spiritual ecology of sacred sites as structuring an animated landscape. It is important to say, however, that in all of these projects, climate change has in no way been a driving force. In cases where a fieldwork agenda consists of mainly seeking confirmation for assumptions of a politically influenced hypothesis, there is no space for accommodating such local rationale.

However, compared with North America, dialogue between government institutions and indigenous peoples regarding resource management is still in its infancy in the northern regions of Europe and Russia (Forbes et al. 2006; Stammler \& Wilson 2006; Stammler \& Peskov 2008). To date, it is mainly Barents region fisheries that approach something like co-management as is practiced in North America, although Norwegian reindeer herding has made efforts in that direction (Jentoft 1998; Hønneland 1999). In Arctic Russia, power-sharing arrangements are generally absent with regard to both non-renewable and renewable resource management, and the urgent question of indigenous entitlement to land remains more or less unresolved (Osherenko 2001; Stammler 2005; Forbes 2008; Stammler \& Peskov 2008).

Although the climate of YNAO and NAO has warmed considerably since about 1980 (Symon et al. 2005; Solomon et al. 2007), the dialogue between Nenets and regional and state administrators has tended to revolve around other matters, especially oil and gas development (Stammler 2002; Nuttall et al. 2005; Stammler \& Forbes 2006). Huntington \& Fox (2005) have similarly observed that on Kola Peninsula, and even to some extent in Nunavut, people outside of the indigenous leadership tend to have other, more pressing, concerns than climate change (see also Griffiths 2007).

During extensive, mostly ecological, fieldwork between 1991 and 1999, conducted by Forbes (BCF), including two annual meetings of the Russian Reindeer Herders' Association, climate change was never raised as a topic of discussion. Much more immediate concerns during this period arose from the wide range of environmental, social and economic impacts of gas extraction and related infrastructure development on Yamal Peninusula (Chance $\delta$ Andreeva 1995; Forbes 1995; Pika \& Bogoyavlensky 1995; Golovnev \& Osherenko 1999). This brings into question whether or not a climate change research agenda is appropriate for Arctic Russia, and other regions and countries where different concerns are paramount.

Nonetheless, Nenets reindeer herders and fisherfolk, through their continuous involvement with the land and its resources, have an extensive memory and expertise on how climate and weather influence their lifestyle. Internationally funded research projects on climate change increasingly include the human dimensions, and Nenets perceptions of and adaptations to climate change have become part of the research interest. Researchers in the European Union-funded Barents Sea Impact Study (BASIS) and Global Change Vulnerabilities in the Barents Region: Linking Arctic Natural Resources, Climate Change and Economies (BALANCE) projects attempted to incorporate "engaging with the tundra" (Stammler 2005, chapter 6) as a process into the research, specifically through migrating with reindeer herders, discussing matters of immediate concern "on the move" on a dayto-day basis, and extensively discussing the weather and human-animal relations on the tundra. Even though driven and funded by efforts to address the climate change debate, both projects did justice to herders' perceptions of climate change in terms of understanding what climate change means for them in terms of coping with new or extreme weather conditions.

Whereas in both projects natural scientists and anthropologists jointly lived and worked with herders at their campsites, the BALANCE project paid particular attention to local and indigenous perceptions of weather-related 


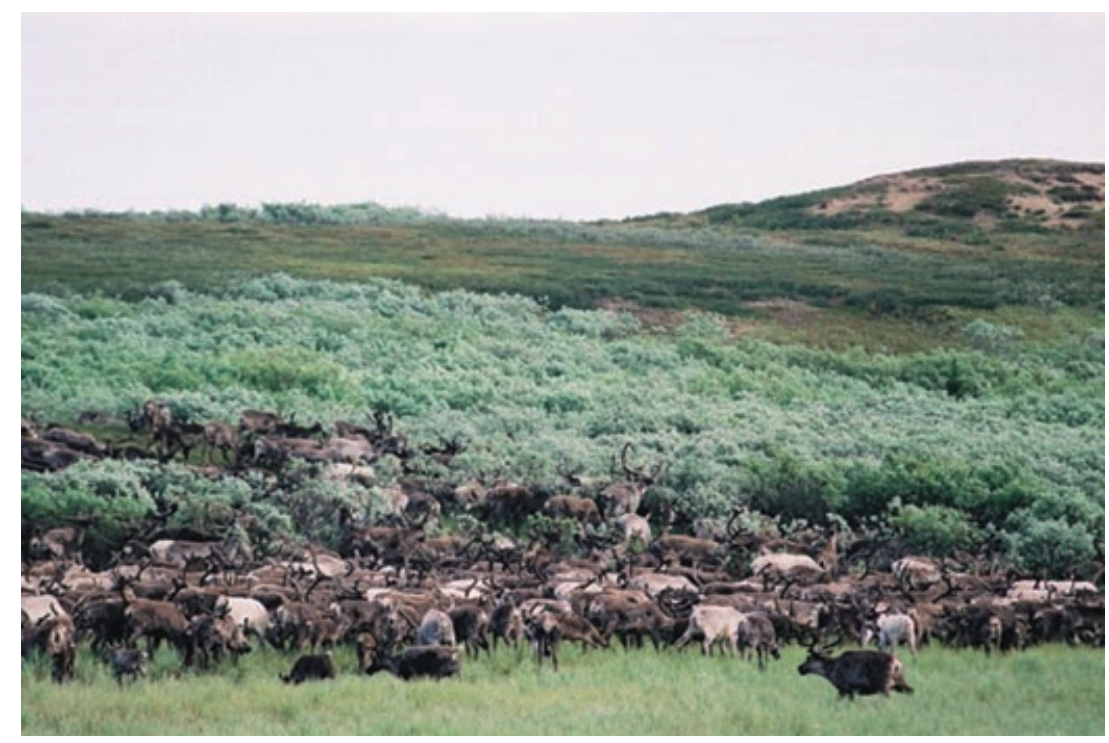

Fig. 2 Reindeer grazing among upright shrub willows (Salix spp.) in the Nenets Autonomous Okrug. Nenets herders here and on Yamal Peninsula have reported that shrubs seem to have increased in height and abundance in recent decades. The tallest shrubs exceed the height of antlers of standing reindeer. (Photo by F. Stammler.) phenomena. Since 1998, Stammler (FMS) has engaged in intensive social anthropological fieldwork to understand the causes contributing to the widely perceived "success" of Yamal Nenets herders compared with their counterparts elsewhere in post-Soviet Russia. Extended to the European Nenets herders since 2003, this work allowed for ample opportunity to participate in and document day-to-day life through the different seasons, which happened to encompass some examples of what has come to be called "extreme weather". One of the main findings of the BALANCE anthropological fieldwork was that climate change was not the main problem people were dealing with on a day-to-day basis, at a time where even basic needs could not be satisfied after the end of the Soviet Union (Rees et al. 2008). Herders had to spend all of their time and energy time to maintain their reindeer herds, and at the same time supply themselves with imported staples such as bread, tea and sugar, all of which had previously been dealt with by the all-caring Soviet state farm. Under such conditions, asking questions about climate change would have been answered by either laughter or silence.

Extremely elaborate ways of knowing evolved out of the joint herd management in summer, where FMS's team, in cooperation with student assistants, Nenets specialists and herders spent their days and nights with the herds, monitoring and managing their movement in the hottest time of the year (July-August). The day-to-day movement of herds 5 and 6 of the kolkhoz Vyucheiskogo was monitored by GPS, and herd behaviour was discussed in relation to the change in weather. This group was of particular interest, because herders there had been working on a fly-in/fly-out shift-work regime between their village and the tundra for the last 50 years, and had mostly abandoned their native Nenets language in favour of Russian, a process that is in popular, as well as some academic discussions, regarded as a loss of distinctive cultural knowledge (Harrison 2007). Among the findings were both short-term responses and long-term perceptions of changes. This case revealed how the day-to-day movement of the herd is a complex reaction to air temperature, humidity, mosquito harassment, wind direction and animal strength. Grazing habits are also influenced by the microtopography of the area and the familiarity of the herd with their pastures. Herders considered these and other factors when they decided to direct the herd to particular places (Rees et al. 2008).

Most notably, they blocked the herd from grazing in large areas of high willow shrubs (e.g., Salix lanata, Salix glauca; Fig. 2). The latter had reportedly increased in height, density and extent as a result of a number of factors, which the herders did not want to evaluate: they said that in the last 50 years there were both very warm and cold periods, but that the shrubs had been only knee-high when they were children. Grazing pressure in the area had also decreased by 50\% between 1992 and 2002, so that there was less harvesting of the shrubs (Rees et al. 2008). The decrease of animals resulted from the loss of state subsidies and institutional disorder after the Soviet Union, i.e., purely social-political reasons.

Winter fieldwork in the same area revealed that the main weather-related concern among herders is snow texture and snow depth. Rain-on-snow in winter, followed by thawing and refreezing, causes gololed, iced-over pastures, where lichen mats are covered by an ice crust, rendering them inaccessible to reindeer (Fig. 3). Herders 


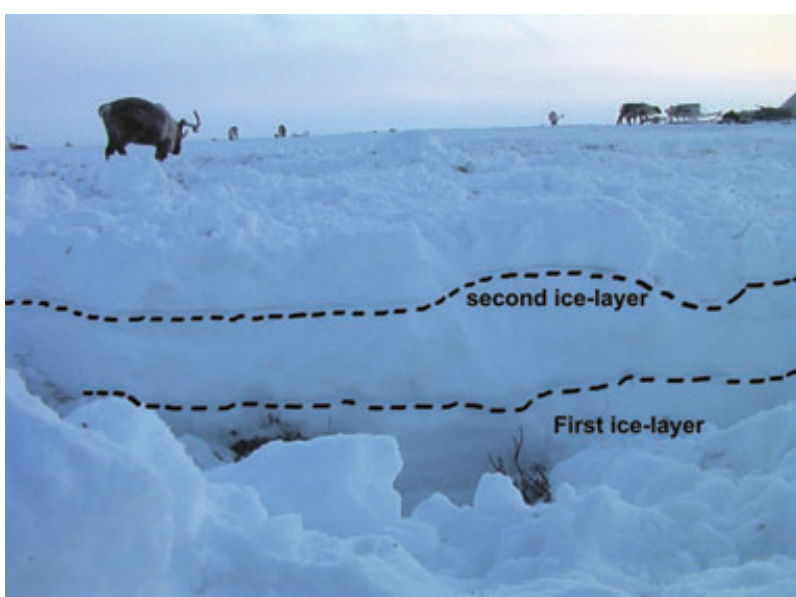

Fig. 3 Layers formed during a major two-stage icing event on the southern Yamal Peninsula in November 2006. The affected area covered an estimated $60 \times 60 \mathrm{~km}$. The same area was affected by an even more extensive icing event a few months later in January 2007, covering approximately $60 \times 100 \mathrm{~km}$, and causing a large number of animals to perish. (Photo by F. Stammler.)

have elaborate memories of the most severe icing events historically, which cost the lives of many animals. Notably, the most significant icing event coincided in time with the campaign of the Soviet Union to establish settled populations in the NAO in 1954. It is therefore difficult to judge if the animals died of hunger because of ice on the pastures, or if their numbers decreased because of forcibly settled herders slaughtering their private animals, or having to abandon them, as a result of pressure from the authorities.

This fieldwork evidence is relevant along three important lines. Firstly, Nenets' adaptation strategies are in general more geared to individual weather events, even though their development as a culture has encompassed a millennium of dramatic climate change (Krupnik 1993; Fedorova 1998). Secondly, even in cases where it is not appropriate to single out climate change as a main concern of the people, it is still possible to contribute rich research evidence from the ground. Thirdly, a group of people who had been under intensive pressure by a totalitarian state, including deportation, forced settlement and confiscation of private herds, and who had mostly lost their native language, still retained all the crucial skills to maintain close-herding of large reindeer herds in a rapidly changing environment. Particular ways of engaging with the environment are encoded in native languages, and Harrison has argued that languages are "important to humanity and to science for the kinds of cultural knowledge they contain" (Harrison 2007: 236). However, the European Nenets of Malozemel'skaia tundra show that such a reduction of "linguo-diversity" is not necessarily accompanied by a reduction of culturally embedded practices. For example, not knowing the many dozens of different terms for lichen does not inhibit European Nenets herders from knowing all their different characteristics and significance for reindeer diet. So, elaborate knowledge of terms for weather in indigenous languages, as studied by indigenous scholars concerned with climate change (Magga 2006), may be one, but not the only, authoritative indicator of the indigenous knowledge that a group retains.

Another possible approach is rather inductive, where researchers define the topics of projects according to local concern, rather than bringing global agendas to the ground. Over a 4-year period (2004-07), both authors took part in a project-Environmental and Social Impacts of Industrial Development in Northern Russia (ENSINOR) - that was directly inspired by the collective and ongoing concern among scientists (Vilchek 1997; Khitun \& Rebristaya 2002; Stammler 2002) and Nenets (Okotetto \& Forbes 1999; Khorolya 2002) about the comprehensive impacts of oil and natural gas development. Although the ENSINOR project was designed to address primarily impacts from oil and gas development, the scientists involved were all fully cognizant of the documented regional climate warming, and so were keen to learn if herders had any relevant observations, perceptions and/or concerns in this sphere.

BCF was particularly interested in evidence of increasing shrub abundance, as this had been tentatively linked with recent warming in the nearly polar Urals (Shvartsman et al. 1999), and had been reported by herders themselves in NAO, as described above. FMS studied decision-making and contacts on the ground between reindeer herders and industry workers. One main finding was that in the absence of effective vertical communication within the interest groups, spontaneous ad hoc decisions in response to particular problems on the ground are of utmost importance. For example, in winter 2006, a large refreezing event in the area north of YarSale on the Yamal Peninsula affected several large herds and camps, just before the annual counting and slaughter campaign (Fig. 3). Herders agreed that an event of this magnitude should be tackled in an agreement between the chairman of the herding enterprise, the local authorities and the gas company with the best transport resources. However, this was not achieved, and herding camps decided individually how to proceed with migration to circumvent iced-over pastures.

Thus, on the one hand, co-management of natural resources on the surface ("wildlife", including reindeer) and sub-surface (hydrocarbons), is unlikely to develop in Arctic Russia in the foreseeable future. On the other hand, the Nenets herders of the Yamal tundra enjoy a degree of 
autonomy and flexibility in the management of their large herds that facilitates resilience at the level of the socialecological system (Stammler 2002). It is more important for the time being that herders develop management equity in the sphere of oil and gas development (Forbes 2008), although we have shown that research related to climate and weather has been carried out in the past. At the same time, TEK-oriented research designed in the West by scientists (both non-indigenous and indigenous) to address climate change, among other aspects of "vulnerability", has recently been introduced to Russia in conjunction with the IPY (e.g., Ealát, Community Adaptation and Vulnerability in Arctic Regions [CAVIAR]), and will surely continue into the future after the close of the IPY.

Opening the doors to international collaboration between indigenous groups is, of course, to be celebrated. However, researchers in this new and exciting endeavour must be extremely mindful of introducing potential investigator effects. In other words, it is incumbent upon scientists proposing to document TEK to avoid presenting climate change as a primary research objective (Norton 2002). To do so in advance can influence collaborators, who may perceive manifestations of global warming in any local anomalies.

\section{Conclusions}

The long-term research of both authors with Nenets reindeer herders in western Siberia and Europe reveals how concepts of climate change, wildlife management and TEK have arrived in the Russian North, mainly as imports from the Western research community, and are received there with careful skepticism. Our findings support the view that issues other than climate change and TEK dominate local concerns, as well as Russian discourses, which focus more on the post-Soviet transformation of society and the impacts of Arctic hydrocarbon resource extraction. We suggest that this skepticism is pointing to divergent views of people on the ground, who are necessarily concerned about changes influencing their dayto-day practices, versus the indigenous leadership, who are more concerned with broader political agendas. This might also apply for northern regions beyond Russia. Research developed in collaboration with the local population focuses on these issues (The Challenges of Modernity for Reindeer Management [RENMAN], ENSINOR), whereas research designed by the West and implemented in Russia (BASIS, BALANCE) does better when it flexibly reinterprets its own agendas. We argue that the best results are obtained by collaborating with herders on topics of weather, instead of climate change, herding skills, instead of wildlife management, and ways of engaging with the tundra, instead of TEK. Participant observation and unstructured interviews help to remind researchers that scientific categories such as "natural change" and "social change" do not necessarily match people's memories. Therefore, they do not influence their practices on the land. The main influencing factor is that practice on the land is a dynamic process that decisively influences people's perceptions of change. The latter proves to consist of a complex set of factors, including social and natural aspects. It is therefore artificial to divide these aspects, as shown in the example of herders' perception of and response to icing events on pastures in 1954 and 2006.

We caution against a rush to analyse adaptation to ongoing rapid climate change through the eyes of the local people in Russia's North by using prevailing Western approaches. Contemporary Nenets society is subject to a number of strong environmental and socio-economic pressures. Nenets therefore practice adaptation in a number of spheres, including, but not limited to, weather, climate and large-scale hydrocarbon development. We have argued in this paper that climate change, adaptation and reindeer management must be carefully placed in their proper context and temporal framework. This is true beyond the Nenets area for other indigenous minorities of Russia's North, where problems of post-Soviet development in the last 18 years have had even greater detrimental effects to indigenous economies (Gray \& Stammler 2002). Western researchers engaged in projects that involve working with northern tundra and taiga inhabitants would do well to remember that they receive their grants as a result of a Western-centric research agenda, the rationale and the principle terms of which (climate change, TEK and wildlife management) are not necessarily deeply shared by their Russian partners. Westernfunded studies that aim to be "community-based" or "community-oriented" within Russia should examine local decisions and their rationales, before attempting to induce wider trends, rather than starting with assumptions and asking for confirmation. If TEK is to be a research topic, we advise against seeking evidence for traditional knowledge "as enframed in the discourse of modernity" (Ingold \& Kurttila 2000: 184), and recommend instead efforts to understand traditional knowledge "as generated in the practices of locality" (Ingold \& Kurttila 2000: 184; Kitti et al. 2006). Recognition of this subtle but critical dichotomy is essential to avoid imposing exogenous constructs, and could be considered a first step in the development of ethical, locally relevant research.

We do not wish to strengthen a prevailing perception of the situation in modern Russia as being irreconcilably 
different from everywhere else (e.g., Einarsson et al. 2004). Rather, we point to a general problem with imposing a science policy agenda onto a Northern populace simply because politicians have decided to allocate substantial funds to particular topics. The same can be said for co-management regimes, as the cases discussed here from North America reveal (e.g., Nadasdy 2005; Stevenson 2006; White 2006). In North America, for example, indigenous leaders stress their observations of climate change to make a political point about their rights to practice traditional livelihoods, whereas governmental institutions increasingly engage Northern residents concerning these same livelihoods primarily via wildlife co-management and TEK, creating a perception within Russia that indigenous peoples elsewhere are only concerned with these matters. A more broadly applicable problem is that by engaging with these processes we may fail to actually hear the voices of active tundra residents relaying their own concerns about the potential for anticipating and adapting to ongoing changes, environmental or otherwise. At the most basic level, if you need to get on with your work and your life on the land and sea, you don't necessarily also have time to make yourself heard politically, regardless of whether you reside in Arctic Russia, Europe or North America. Greater sensitivity to local concerns arising out of ways of engaging with the tundra need not preclude the simultaneous undertaking of research, adhering to a broader scientific and political agenda, addressing climate change. However, a successful combination of the two does require thoughtful effort towards the melding of top-down and bottom-up research priorities.

\section{Acknowledgements}

The fieldwork and interpretations reported here stem from recent projects in northern Europe and Russia. The RENMAN (2001-04) and BALANCE projects (2003-05) were funded by the European Union's 5th Framework Programme (contract numbers QLK5-CT-2000-0745 and EVK2-2002-00169, respectively). The projects ENSINOR (2004-07, under the auspices of the Russia in Flux programme, Decision no. 208147) and BOREAS MOVEINNOCOM (2006-10, Decision no. 118702) have been supported by the Academy of Finland. Additional support for fieldwork came from BBC Wales, the US National Science Foundation Office of Polar Programs, and the National Aeronautics and Space Administration through the Northern Eurasian Earth Science Partnership Initiative. BCF has also benefited intellectually from his involvement in the Adaptive Co-Management Network.

\section{References}

Anderson D. 2000. Identity and ecology in Arctic Siberia: the Number One reindeer brigade. Oxford: Oxford University Press.

Armstrong T., Rogers G. \& Rowley G. 1978. The circumpolar North. New York: Methuen.

Beach H. 2000. Reindeer-pastoralism politics in Sweden: protecting the environment and designing the herder. In A. Hornborg \& G. Palsson (eds.): Negotiating nature: culture, power and environmental argument. Pp. 179-211. Lund: Lund University Press.

Berger T.R. 1977. Northern frontier, northern homeland: the report of the Mackenzie Valley Pipeline Inquiry. Ottawa: Minister of Supply and Services Canada.

Berkes F. 1999. Sacred ecology: traditional ecological knowledge and resource management. Philadelphia: Taylor \& Francis.

Berkes F., Armitage D. \& Doubleday N. 2007. Synthesis: adapting, innovating, evolving. In D. Armitage et al. (eds.): Adaptive co-management: collaboration, learning and multi-level governance. Pp. 308-327. Vancouver: University of British Columbia Press.

Berkes F. \& Jolly D. 2001. Adapting to climate change: social-ecological resilience in a Canadian western Arctic community. Conservation Ecology 5(2), article no. 18.

Bolen E.G. \& Robinson W. 2002. Wildlife ecology and management. 5th edn. New York: Prentice Hall.

Bolotova A. 2004. Colonization of nature in the Soviet Union: state ideology, public discourse, and the experience of geologists. Historical Social Research 29(3), 104-123.

Brown P. 2003. Global warming is killing us too, say Inuit. The Guardian, 11 December.

Caulfield R.A. 2004. Resource governance. In N. Einarsson et al. (eds.): Arctic human development report. Pp. 121-138. Akureyri: Stefansson Arctic Institute.

Chance N.A. \& Andreeva E.N. 1995. Sustainability, equity, and natural resource development in northwest Siberia and Arctic Alaska. Human Ecology 23, 217-240.

Chapin F.S. III, Shaver G.R., Giblin A.E., Nadelhoffer K.J. \& Laundre J.A. 1995. Responses of Arctic tundra to experimental and observed changes in climate. Ecology 76, 694-711.

Dahlstrom Å.N. 2003. Negotiating wilderness in a cultural landscape: predators and Saami reindeer herding in the Laponian World Heritage Area. Uppsala: University of Uppsala.

Doubleday N. 1989. Co-management provisions of the Inuvialuit final agreement. In E. Pinkerton (ed.): Co-operative management of local fisheries: new directions for improved management and community development. Vancouver: University of British Columbia Press.

Einarsson N., Larsen J.N., Nilsson A. \& Young O. (eds.) 2004. Arctic human development report. Akureyri: Stefansson Arctic Institute.

Fedorova N.V. (ed.) 1998. Ušedšie v kholmy: kul'tura naselenija poberežij severo-zapadnogo Jamala $v$ železnom veke. (Gone to the hills: culture of the coastal residents of the north-western Yamal Peninsula during the Iron Age.) Ekaterinburg: Institute of History and Archaeology. 
Forbes B.C. 1995. Tundra disturbance studies. III. Short-term effects of aeolian sand and dust, Yamal Region, northwest Siberia, Russia. Environmental Conservation 22,335-344.

Forbes B.C. 2005. Wilderness. In M. Nuttall (ed.): Encyclopedia of the Arctic. Pp. 2185-2187. New York: Routledge.

Forbes B.C. 2008. Equity, vulnerability and resilience in social-ecological systems: a contemporary example from the Russian Arctic. Research in Social Problems and Public Policy 15, 203-236.

Forbes B.C., Bölter M., Müller-Wille L., Hukkinen J., Müller F., Gunslay N. \& Konstantinov Y. (eds.) 2006. Reindeer management in northernmost Europe: linking practical and scientific knowledge in social-ecological systems. Berlin: Springer.

Fox S. 2002. These are things that are really happening: Inuit perspectives on the evidence and impacts of climate change on Nunavut. In I. Krupnik \& D. Jolly (eds.): The Earth is faster now: indigenous observations of Arctic environmental change. Pp. 13-53. Fairbanks: Arctic Research Consortium of the US.

GISS (Goddard Institute for Space Studies) 2009. GISS surface temperature analysis. Accessed on the internet at http:// data.giss.nasa.gov/gistemp/maps/ on 14 January 2009.

Golovnev A.V. \& Osherenko G. 1999. Siberian survival: the Nenets and their story. Ithaca, NY: Cornell University Press.

Gray P. \& Stammler F. 2002. Siberia caught between collapse and continuity. Max Planck Research 2002, 54-61.

Griffiths F. 2007. Camels in the Arctic? Climate change as the Inuit see it: "from the inside out." The Walrus Magazine, November.

Habeck J.O. 2005. What it means to be a herdsman: the practice and image of reindeer husbandry among the Komi of northern Russia. Münster: Lit.

Harrison K.D. 2007. When languages die. The extinction of the world's languages and the erosion of human knowledge. Oxford: Oxford University Press.

Hinzman L.D., Bettez N.D., Bolton W.R., Chapin F.S., Dyurgerov M.B., Fastie C.L., Griffith B., Hollister R.D., Hope A., Huntington H.P., Jensen A.M., Jia G.J., Jorgenson T., Kane D.L., Klein D.R., Kofinas G., Lynch A.H., Lloyd A.H., McGuire A.D., Nelson F.E., Oechel W.C., Osterkamp T.E., Racine C.H., Romanovsky V.E., Stone R.S., Stow D.A., Sturm M., Tweedie G.E., Vourlitis G.L., Walker M.D., Walker D.A., Webber P.J., Welker J.M., Winker K.S., Yoshikawa K. 2005. Evidence and implications of recent climate change in northern Alaska and other Arctic regions. Climatic Change 72, 251-298.

Hønneland G. 1999. Co-management and communities in the Barents Sea fisheries. Human Organization 58, 397-404.

Huntington H.P. 1992. The Alaska Eskimo Whaling Commission and other cooperative marine mammal management organizations in northern Alaska. Polar Record 28, 119-126.

Huntington H.P. 2000. Using traditional ecological knowledge in science: methods and applications. Ecological Applications 10, 1270-1274.
Huntington H.P. 2005. We dance around in a ring and suppose: academic engagement with traditional knowledge. Arctic Anthropology 42, 29-32.

Huntington H.P. \& Fox S. 2005. The changing Arctic: indigenous perspectives. In C. Symon et al. (eds.): Arctic climate impact assessment. Pp. 61-98. Cambridge: Cambridge University Press.

Ingold T. 2000. The perception of the environment: essays in livelihood, dwelling and skill. London: Routledge.

Ingold T. 2005. A manifesto for the anthropology of the North. In A. Sudkamp (ed.): Connections: local and global aspects of Arctic social systems. Pp. 61-71. Fairbanks: International Arctic Social Sciences Association.

Ingold T. 2007. Conversations from the North. In P. Kaankanpää et al. (eds.): Knowledge and power in the Arctic. Pp. 11-15. Rovaniemi: Arctic Centre, University of Lapland.

Ingold T. \& Kurttila T. 2000. Perceiving the environment in Finnish Lapland. Body and Society 6, 183-196.

Jentoft S. (ed.) 1998. Commons in a cold climate: coastal fisheries and reindeer pastoralism in north Norway. Paris: Parthenon Publishers.

Jia G.J., Epstein H.E. \& Walker D.A. 2003. Greening of Arctic Alaska, 1981-2001. Geophysical Research Letters 30, 31-33.

Jolly D., Berkes F., Castleden J., Nichols T. \& the Community of Sachs Harbour 2002. We can't predict the weather like we used to: Invialuit observations of climate change, Sachs Harbour, western Canadian Arctic. In I. Krupnik \& D. Jolly (eds.): The Earth is faster now: indigenous observations of Arctic environmental change. Pp. 93-125. Fairbanks: Arctic Research Consortium of the US.

Kendrick A. 2003. Caribou co-management in northern Canada: fostering multiple ways of knowing. In F. Berkes et al. (eds.): Navigating social-ecological systems. Building resilience for complexity and change. Pp. 241-267. Cambridge: Cambridge University Press.

Khariutschi S., Sohlberg S. \& Sulyandziga P. 2002. The conservation value of sacred sites of indigenous peoples of the Arctic: a case study in northern Russia. Moscow: Russian Association of Indigenous Peoples of the North.

Kharjuči [Khariutschi] G.P. 2001: Tradicii $i$ innovacii $v$ kul'ture neneckogo etnosa (vtoraja polovina XX veka). (Traditions and innovations in the culture of the Nenets ethnosis [2nd half of the 20th Century].) Tomsk: Tomsk University Publishers.

Khitun O. \& Rebristaya O. 2002. Anthropogenic impacts on habitat structure and species richness in the West Siberian Arctic. In A.E. Watson et al. (eds.): Wilderness in the circumpolar North: searching for compatibility in ecological, traditional, and ecotourism values. Proceedings RMRS-P-26. Pp. 85-95. Ogden, UT: US Dept. of Agriculture, Forest Service, Rocky Mountain Research Station.

Khorolya D. 2002. Reindeer husbandry in Russia. In S. Kankaanpää (ed.): The 2nd World Reindeer Herders' Congress: Anár 2001. Arctic Centre Reports 36. Pp. 40-42. Rovaniemi: Arctic Centre, University of Lapland. 
Kitti H., Gunslay N. \& Forbes B.C. 2006. Defining the quality of reindeer pastures: the perspectives of Sámi reindeer herders. In B.C. Forbes et al. (eds.): Reindeer management in northernmost Europe: linking practical and scientific knowledge in social-ecological systems. Pp. 141-165. Berlin: springer.

Kofinas G. with the communities of Aklavik, Arctic Village, Old Crow \& Fort McPherson. 2002. Community contributions to ecological monitoring: knowledge co-production in the U.S.-Canada Arctic borderlands. In I. Krupnik \& D. Jolly (eds.): The Earth is faster now: indigenous observations of Arctic environmental change. Pp. 55-91. Fairbanks: Arctic Research Consortium of the US.

Krupnik I. 1993. Arctic adaptations: native whalers and reindeer herders of northern Eurasia. Hanover: University Press of New England.

Krupnik I. 2000. Reindeer pastoralism in modern Siberia: research and survival in the time of crash. Polar Research $19,49-56$.

Krupnik I. \& Jolly D. (eds.) 2002. The Earth is faster now: indigenous observations of Arctic environmental change. Fairbanks: Arctic Research Consortium of the US.

Kruse J.A., White R.G., Epstein H.E., Archie B., Berman M., Braund S.R., Chapin F.S. III, Charlie J., Daniel C.J., Eamer J., Flanders N., Klein D.R., Kofinas G., Martin S.M., Murphy S.T., Nebesky W., Nicolson C., Peter K., Russell D.E., Tetlichi J., Tussing A., Walker M.D. \& Young O.R. 2004. Modelling sustainability of Arctic communities: an interdisciplinary collaboration of research and local knowledge holders. Ecosystems 7, 815-828.

Magga O.H. 2006. Diversity in Saami terminology for reindeer, snow, and ice. International Social Science Journal $58,25-34$.

Muraško [Murashko] O. 2001. Kak zastavit' rabotat' Federal'nyj zakon o territorijah tradicionnogo prirodopol'zovanija. (How to make the Federal Law on Territories of Traditional Nature Use work.) Mir korennyh narodov-Živaja arktika (Indigenous Peoples' World_Living Arctic) 8, 20-23. (An English summary of this article was published in ANSIPRA Bulletin 6B, 2002, 3, accessed on the internet at http://npolar.no/ansipra on 2 February 2009.)

Nadasdy P. 2003. Re-evaluating the co-management success story. Arctic 56, 367-380

Nadasdy P. 2005. The anti-politics of TEK: the institutionalization of co-management discourse and practice. Anthropologica 47, 215-232.

Nadasdy P. 2007. Adaptive co-management and the gospel of resilience. In D. Armitage et al. (eds.): Adaptive co-management: collaboration, learning and multi-level governance. Pp. 208-227. Vancouver: University of British Columbia Press.

Nash R. 1982 Wilderness and the American mind. New Haven: Yale University Press.

Natcher D.C, Huntington O., Huntington H., Chapin F.S. III, Trainor S.F. \& DeWilde L.O. 2007. Notions of time and sentience: methodological considerations for Arctic climate change research. Arctic Anthropology 44, 113-126.
Nelson R.K. 1969: Hunters of the northern ice. Chicago: University of Chicago Press.

Norton D.W. 2002. Coastal sea watch: private confessions of a convert to indigenous knowledge. In I. Krupnik \& D. Jolly (eds.): The Earth is faster now: indigenous observations of Arctic environmental change. Pp. 127-155. Fairbanks: Arctic Research Consortium of the US.

Nuttall M., Berkes F., Forbes B.C., Kofinas G., Vlassova T. \& Wenzel G. 2005. Hunting, herding, fishing and gathering: indigenous peoples and renewable resource use in the Arctic. In C. Symon et al. (eds.): Arctic climate impact assessment. Pp. 649-690. Cambridge: Cambridge University Press.

Okotetto M.N. \& Forbes B.C. 1999. Conflicts between Yamal-Nenets reindeer husbandry and petroleum development in the forest tundra and tundra region of northwest Siberia. In S. Kankaanpää et al. (eds.): Sustainable development in timberline forests. Pp. 95-99. Helsinki: Finnish Forest Research Administration.

Osherenko G. 1988. Sharing power with Native users: co-management regimes for Native wildlife. Working Paper No. 5. Ottawa: Canadian Arctic Resources Committee.

Osherenko G. 2001. Indigenous rights in Russia: is title to land essential for cultural survival? The Georgetown International Environmental Law Review 13, 695-733.

Pika A. 1999. Neotraditionalism in the Russian North: indigenous peoples and the legacy of perestroika. Edmonton: Canadian Circumpolar Institute Press.

Pika A. \& Bogoyavlensky D. 1995. Yamal Peninsula: oil and gas development and problems of demography and health among indigenous populations. Arctic Anthropology 32, 61-74.

Plotnikova V.V. (ed.) 1997. Èkologia Hanty-Mansijskogo avtonomnogo okruga. (Ecology of the Khanty-Mansiiskogo Autonomous Okrug.) Tjumen: Soft Design.

Rees W.G., Stammler F., Danks F.S. \& Vitebsky P. 2008. Vulnerability of European reindeer husbandry to global change. Climatic Change 87, 199-217.

Riedlinger D. \& Berkes F. 2001. Contributions of traditional knowledge to understanding climate change in the Canadian Arctic. Polar Record 37, 315-328.

Serreze M.C. \& Francis J.A. 2006. The Arctic amplification debate. Climatic Change 76, 241-264.

Shvartsman Y.G., Barzut V.M., Vidyakina S.V. \& Iglovsky S.A. 1999. Climate variations and dynamic ecosystems of the Arkhangelsk region. Global Change Biology 1, 417-428.

Solomon S., Qin D., Manning M., Chen Z., Marquis M., Averyt K., Tignor M.M.B. \& Miller H.L. Jr. (eds.) 2007. Climate change 2007. The physical science basis. Contribution of Working Group I to the fourth assessment report of the Intergovernmental Panel on Climate Change. Cambridge: Cambridge University Press.

Stammler F. 2002. Success at the edge of the land: present and past challenges for reindeer herders of the West-Siberian Yamal-Nenets autonomous Okrug. Nomadic Peoples 6, 51-71. 
Stammler F. 2005. Reindeer nomads meet the market: culture, property and globalisation at the "end of the land". Münster: Lit.

Stammler F. \& Forbes B.C. 2006. Oil and gas development in the Russian Arctic: West Siberia and Timan-Pechora. Indigenous Affairs 2-3/06, 48-57.

Stammler F. \& Peskov V. 2008. Building a "culture of dialogue" among stakeholders in north-west Russian oil extraction. Europe-Asia Studies 60, 831-849.

Stammler F. \& Ventsel A. 2003. Between neoliberalism and dirigisme: approaches to reindeer herding in Yamal and Sakha. In C.M. Hann (ed.): The post-socialist agrarian question: property relations and the rural condition. Pp. 321-362. Münster: Lit.

Stammler F. \& Wilson E. 2006. Dialogue for development: an exploration of relations between oil and gas companies, communities and the state. Sibirica 5(2), 1-42.

Stevenson M.G. 2006. The possibility of difference: rethinking co-management. Human Organization 65, 167-183.

Sturm M., Racine C. \& Tape K. 2001. Increasing shrub abundance in the Arctic. Nature 411, 546-547.

Sturm M., Schimel J., Michaelson G., Welker J.M., Oberbauer S.F., Liston G.E., Fahnestock J. \& Romanovsky V.E. 2005. Winter biological processes could help convert Arctic tundra to shrubland. BioScience 55, 17-26.

Symon C., Arris L. \& Heal B. 2005. Arctic climate impact assessment. Cambridge: Cambridge University Press.

Treseder L. 1999. The evolution and status of wildlife co-management in Canada. In L. Treseder \& J. Honda-McNeil (eds.): Northern Eden: community based wildife management in Canada. Pp. 7-18. Edmonton: University of Alberta.

Turi J.M. 2000. Native reindeer herders' priorities for research. Polar Research 19, 131-133.

Tyler N.J.C., Turi J.M., Sundset M.A., Strøm Bull K., Sara M.N., Reinert E., Oskal N., Nellemann C., McCarthy J.J., Mathiesen S.D., Martello M.L., Magga O.H., Hovelsrud G.K., Hanssen-Bauer I., Eira N.I., Eira I.M.G. \& Corell R.W. 2007. Saami reindeer pastoralism under climate change: applying a generalized framework for vulnerability studies to a sub-Arctic social-ecological system. Global Environmental Change 17, 191-206.

Usher P.J. 1971. The Bankslanders: economy and ecology of a frontier trapping community. Vol.3. The community. Ottawa: Information Canada.

Usher P.J. 1991. Some implications of the Sparrow judgment for resource conservation and management. Alternatives 18(2), 20-21.

Usher P.J. 2000. Traditional ecological knowledge in environmental assessment and management. Arctic 53, 183-193.

Vibe C. 1967. Arctic animals in relation to climatic fluctuations. Meddelelser om Gronland 170(5). Copenhagen: C.A. Reitzels.

Vilchek G.E. 1997. Arctic ecosystem stability and disturbance: a West Siberian case history. In R.M.M. Crawford (ed.): Disturbance and recovery in Arctic lands: an ecological perspective. Pp. 179-189. Dordrecht: Kluwer Academic.

Vitebsky P. 1995. From cosmology to environmentalism: shamanism as local knowledge in a global setting. In R. Fardon (ed.): Counterworks: managing the diversity of knowledge. Pp. 182-203. London: Routledge.

Vitebsky P. 2005. Reindeer people: living with animals and spirits in Siberia. London: Harper Collins.

Weiner D. 1988. Models of nature. ecology, conservation and cultural revolution in Soviet Russia. Bloomington: Indiana University Press.

Wenzel G.W. 1991. Animal rights, human rights: ecology, economy and ideology in the Canadian Arctic. Toronto: University of Toronto Press.

White G. 2006. Cultures in collision: traditional knowledge and Euro-Canadian governance processes in Northern land-claim boards. Arctic 59, 401-414.

Young O.R. 1992. Arctic politics: conflict and cooperation in the circumpolar North. Dartmouth: University Press of New England.

Zimov S.A., Schuur E.A.G. \& Chapin F.S. III. 2006. Permafrost and the global carbon budget. Science 312, 1612-1613. 